\title{
Performance, water intake, carcass characteristics and intestinal histomorphology of broilers supplemented with phytase
}

\author{
L. van Emmenes, E. Pieterse ${ }^{\#}$ \& L.C. Hoffman \\ Department of Animal Sciences, Stellenbosch University, Private Bag X1, Matieland 7602, South Africa
}

(Received 29 June 2015; Accepted 1 July 2018; First published online 7 September 2018)

\begin{abstract}
Copyright resides with the authors in terms of the Creative Commons Attribution 4.0 South African Licence.
See: http://creativecommons.org/licenses/by/4.0/za

Condition of use: The user may copy, distribute, transmit and adapt the work, but must recognise the authors and the South African Journal of Animal Science.
\end{abstract}

\begin{abstract}
A 32-day experiment was conducted to study the effects of supplementation of phytase enzyme, Ronozyme ${ }^{\circledR}$ HiPhos (DSM Nutritional Products, Basel, Switzerland), on the production parameters, water intake, intestinal histomorphology, carcass characteristics and bone mineralization of broiler chickens. A total of 1920 one-day-old Cobb 500 broilers were randomly allocated to one of three treatments, each comprising eight replicate cages (eight replications per treatment) with 80 birds per cage. Dietary treatments were created using a standard commercial diet as the positive control (CON); reducing the nutrient content of the CON diet with values similar to the matrix values of 1500 FYT (phytase units) Ronozyme ${ }^{\circledR}$ HiPhos to create the negative control diet (NEG); and supplementing the NEG diet with 1500 FYT/kg Ronozyme HiPhos to create the phytase diet (HiPhos). Supplementation of the NEG diet with HiPhos significantly improved average daily gain (ADG), feed conversion ratio (FCR), bodyweight (BW) at slaughter and the European production efficiency factor (EPEF) of broilers compared with those in the NEG treatment group, but had no effect on total feed intake, water intake, villi height, crypt depth, dressing percentage, portion yields, $\mathrm{pH}$ of the meat or colour of the meat. Fat-free bone ash percentage and tibia breaking strength of broilers in the HiPhos treatment group were intermediate to broilers in the NEG and CON treatment groups. Results from the study proved that broilers could be supplemented with HiPhos phytase without detrimental effects on growth parameters, bone mineralization, carcass characteristics and water intake.
\end{abstract}

Keywords: Bone breaking strength, chickens, phosphorus, villus height, weight gain

\# Corresponding author: elsjep@sun.ac.za

\section{Introduction}

Plants are a major source of dietary phosphorus (P), but approximately $60 \%$ to $85 \%$ of the total $P$ in common feed ingredients is bound in the form of phytic acid or phytate (Ravindran et al., 1994; Selle \& Ravindran, 2007). Phosphate groups in phytic acid are negatively charged and are capable of forming complexes with positively charged minerals (Davies \& Olpin, 1979; Cheryan \& Rackis, 1980; Lonnerdal et al., 1989), proteins (Hídvégi \& Lásztity, 2002) and starch (Yoon et al., 1983), rendering these nutrients unavailable for absorption. Phytate-bound $\mathrm{P}$ is poorly utilized by monogastric animals and therefore $\mathrm{P}$ should be added to the diet in the form of feed phosphates to meet their $\mathrm{P}$ requirements. Phytase has the ability to dephosphorylate phytate, thereby, releasing phytate-bound $\mathrm{P}$ and nutrients. Consequently, dietary supplementation with microbial phytase allows reduction of this mineral and nutrients during diet formulation (Selle et al., 1999).

Phosphorus is an important nutrient for proper development and growth in all animals (McDonald et al., 2002). Together with calcium ( $\mathrm{Ca}$ ) and magnesium (Mg), it forms the structural components of the skeleton (Pond et al., 2005). Bone status is important in poultry production and can be used as an indicator of mineral adequacy of the diet. Therefore, the release and bioavailability of phytate-bound $P$ through the use of phytase could be evaluated by responses in live weight gain and bone development (Orban et al., 1999).

Phytate is capable of forming complexes with protein and starch (above). In addition, phytate increases endogenous amino acid losses (Cowieson et al., 2004) and is believed to inhibit digestive enzymes (Singh \& Krikorian, 1982; Deshpande \& Damodaran, 1989; Maenz, 2001). Phytase supplementation should therefore increase the availability of protein and starch. A shift in available energy or 
protein may change the rate of protein and fat deposition (Bikker et al., 1995; Kies et al., 2005). It is hypothesized that this result may have an effect on certain carcass characteristics, for example dressing percentage and cut yield. It is therefore important to consider the effects phytase may have on the appearance and physical characteristics of the meat, as well as its effect on portion sizes. Meat colour and $\mathrm{pH}$ of meat are critical attributes to meat quality. Phytase has been shown to have no negative effects on meat colour, muscle pH (Han et al., 2009) or portion sizes (Scheideler \& Ferket, 2000). However, the literature about changes in carcass characteristics because of phytase supplementation is limited, and more research is warranted to quantify these effects.

Furthermore, phytase supplementation increases mineral availability and decreases endogenous mineral excretion in chickens. Consequently, the osmolality in the gastrointestinal tract of the chicken may increase, which may result in increased demand for water to maintain homeostasis (Cowieson et al., 2004). Any dietary changes that might lead to an increment in water intake are expected to increase excreta and litter moisture, which may affect the health and welfare of the chickens (Youssef et al., 2011). There is a dearth of information and published data on the effect of phytase on water intake in broilers. When one considers the negative effects wet litter may have on the health of chickens, it is important to determine the effect of phytase on water intake. The current study was undertaken to determine the effects of a commercial phytase, namely Ronozyme HiPhos, on production parameters (feed conversion ratio (FCR), bodyweight (BW) at slaughter and the European production efficiency factor (EPEF), water intake, bone mineralization (fat-free bone ash and tibia strength), carcass characteristics (dressing percentage and portion yield) meat quality parameters ( $\mathrm{pH}$ of the meat and colour of the meat) and intestinal histomorphology (villi height and crypt depth) when supplemented to broiler diets with reduced levels of $\mathrm{P}, \mathrm{Ca}$, and amino acids.

\section{Materials and Methods}

A total of 1920 one-day-old as-hatched broiler (Cobb 500) chicks were obtained from a commercial hatchery and randomly allotted to one of three dietary treatment groups, with 80 birds assigned to each of 24 floor pens (eight replications per treatment) with a density of 21.8 chickens $/ \mathrm{m}^{2}$. Each pen was equipped with two tube feeders, a bell drinker, an infrared lamp and fresh shavings. Chickens were kept in a temperaturecontrolled broiler house. Environmental temperature and lightning in the houses were according to the Cobb 500 standard. The experiment was conducted at Mariendahl Experimental Farm of Stellenbosch University. Experimental procedures were approved by the Animal Ethics Committee of Stellenbosch University, reference number SU-ACUM12-00039.

The chicks were assigned to three treatment diets (Table 1). The positive control (CON) was a commercial diet with no added phytase. To formulate the negative control diet (NEG), the matrix values for 1500 FYT (phytase units) Ronozyme ${ }^{\circledR}$ HiPhos were used as a guideline to subtract digestible $P(1.7 \mathrm{~g} / \mathrm{kg})$, $\mathrm{Ca}(2.1 \mathrm{~g} / \mathrm{kg})$, crude protein $(2.3 \mathrm{~g} / \mathrm{kg})$ and apparent metabolizable energy $(0.3 \mathrm{MJ} / \mathrm{kg})$ from the specifications of CON. To create the HiPhos diet, the negative control diet was supplemented with $1500 \mathrm{FYT} / \mathrm{kg}$ HiPhos phytase, a level recommended by the manufacturer. Diets were mixed at Mariendahl Experimental Farm, Stellenbosch. All diets were pelleted at $75{ }^{\circ} \mathrm{C}$. Dietary samples were submitted to DSM (Biopract $\mathrm{GmbH}$, Berlin, Germany) to determine phytase activity. The activity rates of the grower and finisher diets containing phytase were $1302 \mathrm{FYT} / \mathrm{kg}$ and $1399 \mathrm{FYT} / \mathrm{kg}$, respectively. The starter, grower and finisher diets were supplied for 14, 7 and 11 days, respectively.

Water and feed were supplied ad libitum. Mortalities were recorded daily. Feed consumption and bodyweight were recorded each week. From these data, individual feed intake, individual bodyweight, FCR, and EPEF were calculated. To measure water intake, each pen was equipped with a $25 \mathrm{~L}$ bucket connected to a bell drinker. The bucket was filled twice daily and water was weighed out each morning to determine daily water intake per pen. Water intake per bird was calculated as the average of the pen. At 29 days old one bird per pen (eight pens per treatment) was randomly selected from around the mean weight of the chickens in each pen. These birds were slaughtered according to standard commercial practice including electrical stunning (50-70 volts; 3-5 seconds), followed by exsanguination within 10 seconds of stunning. Both tibias were removed and frozen at $-20^{\circ} \mathrm{C}$ for further analysis. The left tibias were thawed, cleaned of adherent tissue and weighed. Tibia breaking strength was determined according to the three-point destructive bending test prescribed by Fleming et al. (1998) using an Instron 3345 material testing machine (model 2519-107) fitted with a three-point-bend rig with a load cell capacity of $5000 \mathrm{~N}$ and crosshead speed of $30 \mathrm{~mm} / \mathrm{min}$. The $18 \mathrm{~mm}$ diameter crosshead probe approached the anterior side of the tibia at $30 \mathrm{~mm} / \mathrm{min}$ until the tibia was broken. Breaking strength $(\mathrm{N})$ was recorded as the point of maximum load before failure occurred. Right tibias were defatted in petroleum ether for 48 hours (Rama Rao \& Reddy, 2001). Subsequently, fat-free bone ash percentage was determined after placing the tibia in a furnace for 24 hours at $600^{\circ} \mathrm{C}$ (Zhang \& Coon, 1997). 
Gut samples were taken of the duodenum (on the gizzard side of the duodenum at the start of the pancreas) within 15 minutes post-mortem. Samples were rinsed with a $0.9 \%$ saline solution and fixed in a $10 \%$ buffered formalin solution. Samples were processed according to the method described in Presnell \& Schreibman (1997). The processing consisted of washing, trimming, dehydration with alcohol, clearing with xylene and impregnation with paraffin wax. Tissue sections of about 3 to $4 \mu \mathrm{m}$ were cut with a microtome, fixed on slides and stained with haematoxylin and eosin dye. Slides were examined with the 2.5X magnification objective lens of a Zeiss Axioxskop2 light microscope, equipped with a digital camera. Images were analysed with AxioVision image-analysis software, version 4.7.2 (Carl Zeiss microscopy). Average villi height and area were measured from the tip of the villi to the villous-crypt junction for 10 consecutive intact villi. Average crypt depth was estimated by measuring 10 crypts per section.

Table 1 Ingredients and calculated nutrient composition of starter, grower and finisher diets

\begin{tabular}{|c|c|c|c|c|c|c|}
\hline & \multicolumn{2}{|c|}{$\begin{array}{l}\text { Starter diet } \\
\text { (Day 0-14) }\end{array}$} & \multicolumn{2}{|c|}{$\begin{array}{l}\text { Grower diet } \\
\text { (Day 14-21) }\end{array}$} & \multicolumn{2}{|c|}{$\begin{array}{c}\text { Finisher diet } \\
\text { (Day 21-32) }\end{array}$} \\
\hline & $\mathrm{CON}^{1}$ & $\mathrm{NEG}^{2}$ & CON & NEG & CON & NEG \\
\hline \multicolumn{7}{|l|}{ Ingredient (g/kg) } \\
\hline Maize & 512.46 & 561.09 & 608.66 & 612.20 & 628.00 & 623.11 \\
\hline Soya bean meal $\left(48 \% \mathrm{CP}^{3}\right)$ & 300.00 & 300.00 & 316.20 & 282.81 & 271.95 & 251.48 \\
\hline Sunflower oilcake (36\% CP) & 60.00 & 60.00 & 0.00 & 70.00 & 0.00 & 70.00 \\
\hline Canola press cake & 40.00 & 24.85 & 0.00 & 0.00 & 10.00 & 10.00 \\
\hline Fish meal & 13.56 & 10.00 & 20.71 & 0.00 & 29.08 & 0.00 \\
\hline Wheat bran & 10.98 & 21.21 & 0.00 & 0.00 & 0.00 & 0.00 \\
\hline Limestone & 9.92 & 9.13 & 10.82 & 10.31 & 10.88 & 10.46 \\
\hline L-Lysine & 0.57 & 0.76 & 0.00 & 0.99 & 0.10 & 1.26 \\
\hline DL-Methionine & 1.61 & 1.68 & 1.92 & 1.84 & 1.74 & 1.73 \\
\hline Monocalcium phosphate & 13.32 & 3.65 & 11.48 & 2.87 & 11.20 & 3.16 \\
\hline Salt & 4.57 & 4.32 & 4.21 & 4.55 & 4.07 & 4.54 \\
\hline Vegetable oil & 30.00 & 0.00 & 23.00 & 11.43 & 30.00 & 21.06 \\
\hline Premix & 3.00 & 3.00 & 3.00 & 3.00 & 3.00 & 3.00 \\
\hline \multicolumn{7}{|l|}{ Calculated nutritional value (g/kg) } \\
\hline Apparent metabolizable energy (MJ/kg) & 12.468 & 12.146 & 12.970 & 12.650 & 13.180 & 12.860 \\
\hline Dry matter & 894.00 & 891.90 & 888.35 & 891.53 & 888.72 & 892.62 \\
\hline Crude protein & 219.00 & 216.75 & 200.00 & 197.69 & 190.00 & 187.66 \\
\hline Crude fibre & 45.93 & 46.75 & 34.03 & 43.77 & 33.30 & 43.44 \\
\hline Calcium (Ca) & 9.00 & 6.92 & 8.80 & 6.72 & 8.80 & 6.72 \\
\hline Available phosphorus (aP) & 4.32 & 2.34 & 3.88 & 1.88 & 3.96 & 1.91 \\
\hline Digestible phosphorus & 4.11 & 2.41 & 3.71 & 2.01 & 3.71 & 2.01 \\
\hline $\mathrm{Ca}: \mathrm{aP}$ & 2.08 & 2.96 & 2.27 & 3.57 & 2.22 & 3.52 \\
\hline Digestible lysine & 11.00 & 10.91 & 10.05 & 9.90 & 9.60 & 9.50 \\
\hline Digestible methionine & 4.94 & 4.62 & 4.84 & 4.74 & 4.66 & 4.53 \\
\hline Digestible methionine + cysteine & 8.06 & 8.01 & 7.60 & 7.55 & 7.92 & 7.24 \\
\hline Digestible tryptophan & 2.34 & 2.30 & 2.11 & 2.08 & 1.97 & 1.95 \\
\hline Digestible isoleucine & 8.97 & 8.85 & 8.31 & 8.10 & 7.80 & 8.85 \\
\hline Digestible threonine & 7.66 & 7.53 & 7.07 & 6.82 & 6.71 & 6.44 \\
\hline Sodium & 2.00 & 2.01 & 1.90 & 1.90 & 1.90 & 1.91 \\
\hline
\end{tabular}

${ }^{1} \mathrm{CON}$ : control diet (specification of standard feed)

${ }^{2} \mathrm{NEG}$ : negative control diet (specification of standard feed minus the matrix values of $1500 \mathrm{FYT}$ Ronozyme HiPhos)

${ }^{3} \mathrm{CP}$ : crude protein 
At 32 days old, one bird per pen (eight pens per treatment) was randomly selected from around the mean weight of the chickens in each pen, fasted overnight and slaughtered according to standard commercial practice, including electrical stunning followed by exsanguination. The broilers were scalded, defeathered and eviscerated. Initial muscle $\mathrm{pH}\left(\mathrm{pH}_{\mathrm{i}}\right)$ of the breast was determined 15 minutes post mortem using a calibrated portable Crison $\mathrm{pH} 25$ meter (Alella, Barcelona). Ultimate muscle $\mathrm{pH}\left(\mathrm{pH}_{\mathrm{u}}\right)$ was determined 24 hours post mortem. Following the initial $\mathrm{pH}$ measurement, the carcasses were hung in cold storage at $4{ }^{\circ} \mathrm{C}$ for 24 hours. Live weight, hot carcass weight and chilled carcass weight 24 hours post mortem were recorded. Dressing percentage was calculated as the percentage difference between the live weight of the chicken and the weight of the hot carcass. Commercial portion yields were determined by first cutting the cold carcasses in half using a portion cutter. Subsequently, the thigh and drumstick were removed by cutting above the thigh towards the acetabulum and behind the pubic bone. The drumstick and thigh were separated by cutting perpendicular towards the joint connecting these two cuts. The wings were removed from the carcass by cutting through the joint between the scapula and the coracoid. The separate portions were weighed with a Mettler PC4400 scale. Component yield percentages were then calculated by expressing these weights as a percentage relative to chilled carcass weight. Subsequently, the skin of the breast was removed and the muscle was placed on a flat surface and allowed to bloom for 15 min (Warriss, 2000) at $8^{\circ} \mathrm{C}$. Meat colour ( $L^{*}, a^{*}, b^{*}$ measurements) was measured with a ClE-Lab colour meter (BYKGardner $\mathrm{GmbH}$, Geretsried, Germany) in which $\mathrm{L}^{*}$ represents lightness, $\mathrm{a}^{*}$ redness and $\mathrm{b}^{*}$ yellowness (Nollet et al., 2007). Measurements were taken in triplicate over the total area of the muscle and the average was calculated.

Analysis of variance was performed on pen means data using the general linear model and ANOVA procedures of SAS (2009) with treatment as the main effect. All the parameters were tested for normality and homoscedasticity before analysis. Significance was declared at $P<0.05$. Means were separated with a Bonferroni post hoc test (SAS, 2009). Average daily gain (ADG) was determined by fitting a linear regression of the weight over time. The slope of the resulting regression function is ADG and was used to compare animals between treatments.

\section{Results and Discussion}

Chicks supplemented with phytase had significantly higher bodyweights on days 14, 21 and 32 compared with chicks in the NEG treatment group, but were similar $(P>0.05)$ to those in the CON treatment group (Table 2). Compared with the NEG treatment group, chicks in the CON treatment group had a significantly higher bodyweight on day 21 , while no significant differences were observed between these two groups on days 14 and 32. However, over the whole trial period, chicks in the CON and HiPhos treatment had significantly higher ADGs than chicks in the NEG treatment group. Supplementing the NEG diet with $1500 \mathrm{FYT} / \mathrm{kg}$ Ronozyme HiPhos significantly increased live weight gain by $6.1 \%$ and $3.7 \%$ during the grower and finisher phases, respectively. These results were not so pronounced as those found by Shaw et al. (2011), who reported that the addition of $1000 \mathrm{FYT} / \mathrm{kg}$ or $2000 \mathrm{FYT} / \mathrm{kg}$ Ronozyme ${ }^{\circledR}$ HiPhos phytase to broiler diets increased the bodyweight of 21-day-old broilers by $15.5 \%$ and $17.1 \%$, respectively. However, differences between bodyweight of chickens in the positive control and negative control groups in the study of Shaw et al. (2011) were more profound than in the current trial. The differences in bodyweight between the control groups in the current trial and the results reported by Shaw et al. (2011) might be partly explained by the wider dietary $\mathrm{Ca}$ : $\mathrm{P}$ ratios in the latter study. At wider ratios, $\mathrm{Ca}$ may form insoluble Ca-phosphate in the gastrointestinal tract, reducing the absorption of both Ca and P (Hurwitz \& Bar, 1971; Selle et al., 2009). When the $\mathrm{Ca}$ level increases in diets containing low available phosphorus (aP) levels, the $\mathrm{Ca}$ : aP ratio widens, resulting in decreased bodyweight gains (Rama Rao et al., 2006). Furthermore, Driver et al. (2005) reported that phytase supplementation (12000 FYT/kg) was more effective when supplemented to diets with unbalanced $\mathrm{Ca}: \mathrm{P}$ ratios than in balanced diets. These authors concluded that many of the published papers on the effect of $\mathrm{Ca}: \mathrm{P}$ ratio on phytase efficiency are misleading. Reports usually show an increase in performance when phytase is supplemented to narrow $\mathrm{Ca}$ : $\mathrm{P}$ ratios, but the margin of improvement in most studies is substantially greater for birds fed diets with wide $\mathrm{Ca}: \mathrm{P}$ ratios.

Loss of appetite can be an early characteristic of P deprivation (Suttle, 2010), but it was not observed in the current trial in chickens fed diets that were low in aP. Phosphorus levels and phytase supplementation did not affect feed intake in the grower or finisher phases (Table 2). Similarly, Shaw et al. (2011) reported a lack of significant difference for feed intake between broilers fed diets with various non-phytate phosphorus (npP) levels and HiPhos supplementation. Viveros et al. (2002) reported a significant difference in feed intake for broilers on diets with various npP levels, but Natuphos phytase supplementation did not increase feed consumption. On the contrary, Shaw et al. (2010) and Aureli et al. (2011) reported significant differences in feed intake between broilers on diets with different npP levels and in broilers receiving diets with phytase supplementation. However, in the study of Aureli et al. (2011) dietary npP levels $(0.8 \mathrm{~g} / \mathrm{kg})$ were 
extremely low. Moreover, Wu et al. (2006) noted a significant interaction between dietary npP levels and phytase on feed intake. Phytase increased feed intake in layers fed diets with $1.1 \mathrm{~g} / \mathrm{kg} \mathrm{npP}$, but phytase supplementation to diets with $2.2 \mathrm{~g} / \mathrm{kg}$ of $\mathrm{npP}$ had no effect on intake (Wu et al., 2006). Therefore, differences in the results of feed intake among studies may be partially explained by dietary aP or $\mathrm{npP}$ levels. In the current study, phytase supplementation improved FCR compared with the NEG treatment group, presumably through liberation of phytate-bound $P$ and nutrients. These results are in agreement with previous work (Aureli et al., 2011; Shaw et al., 2011). Broilers supplemented with phytase had similar ( $P$ $>0.05$ ) EPEF values compared with broilers in the CON group, but significantly higher EPEF values compared with broilers in the NEG treatment group.

Table 2 Means ( \pm SE) of production parameters and water intake of broilers supplemented with $1500 \mathrm{FYT} / \mathrm{kg}$ phytase

\begin{tabular}{|c|c|c|c|c|}
\hline & \multicolumn{3}{|c|}{ Treatment } & \multirow{2}{*}{$P$-value } \\
\hline & $\mathrm{CON}^{1}$ & $\mathrm{NEG}^{2}$ & HiPhos $^{3}$ & \\
\hline \multicolumn{5}{|l|}{ Bodyweight (g) } \\
\hline Day 0 & $44.0 \pm 0.2$ & $43.9 \pm 0.2$ & $44.1 \pm 0.2$ & $N S^{6}$ \\
\hline Day 14 & $460.3^{\mathrm{ab}} \pm 3.9$ & $446.0^{\mathrm{a}} \pm 5.7$ & $470.8^{\mathrm{b}} \pm 3.4$ & 0.004 \\
\hline Day 21 & $955.4^{b} \pm 13.2$ & $899.9^{a} \pm 4.3$ & $957.9^{\mathrm{b}} \pm 8.2$ & 0.001 \\
\hline Day 32 & $1852.9^{\mathrm{ab}} \pm 13.8$ & $1808.3^{a} \pm 17.0$ & $1878.5^{\mathrm{b}} \pm 10.5$ & 0.015 \\
\hline Average daily gain & $58.46^{\mathrm{b}} \pm 0.3$ & $56.9^{\mathrm{a}} \pm 0.3$ & $58.93^{\mathrm{b}} \pm 0.3$ & $<0.001$ \\
\hline \multicolumn{5}{|l|}{ Feed intake (g) } \\
\hline Day 0-14 (starter) & $598.6^{\mathrm{ab}} \pm 4.2$ & $590.1^{\mathrm{a}} \pm 4.7$ & $607.8^{\mathrm{b}} \pm 2.0$ & 0.018 \\
\hline Day 15-21 (grower) & $748.3 \pm 7.5$ & $740.9 \pm 4.9$ & $762.7 \pm 9.2$ & NS \\
\hline Day 22-32 (finisher) & $1575.0 \pm 15.2$ & $1611.0 \pm 19.1$ & $1612.4 \pm 28.6$ & NS \\
\hline Total feed intake & $2921.9 \pm 21.2$ & $2942.7 \pm 25.2$ & $2982.8 \pm 31.4$ & NS \\
\hline Total water intake (L) & $6.09 \pm 0.09$ & $6.15 \pm 0.06$ & $6.25 \pm 0.09$ & NS \\
\hline $\begin{array}{l}\text { Water intake/ feed } \\
\text { intake }\end{array}$ & $2.09 \pm 0.03$ & $2.09 \pm 0.02$ & $2.11 \pm 0.05$ & NS \\
\hline $\mathrm{FCR}^{4}$ & $1.62^{\mathrm{a}} \pm 0.01$ & $1.67^{\mathrm{b}} \pm 0.01$ & $1.63^{\mathrm{a}} \pm 0.01$ & 0.005 \\
\hline EPEF $^{5}$ & $332.9^{b} \pm 3.7$ & $300.2^{\mathrm{a}} \pm 6.3$ & $326.1^{b} \pm 5.6$ & $<0.001$ \\
\hline Mortalities (\%) & $3.88 \pm 0.85$ & $7.38 \pm 1.24$ & $7.75 \pm 1.90$ & NS \\
\hline
\end{tabular}

${ }^{1}$ CON: normal specification of standard feed

${ }^{2} \mathrm{NEG}$ : normal specification of standard feed minus matrix values of $1500 \mathrm{FYT}$ HiPhos

${ }^{3}$ HiPhos: NEG diet +1500 FYT/kg HiPhos phytase

${ }^{4}$ FCR: feed conversion ratio

${ }^{5}$ EPEF: European production efficiency factor

${ }^{6} \mathrm{NS}$ : not significant $(P>0.05)$

${ }^{a, b}$ Means within rows with different superscripts differ significantly $(P<0.05)$

The increased liberation of $\mathrm{Na}$ and $\mathrm{K}$ by means of phytase, together with the possibility that phytase might decrease endogenous $\mathrm{Na}$ and $\mathrm{Ca}$ excretion (Cowieson et al., 2004), may elevate the osmolality in the gastrointestinal tract, resulting in an increased demand for water to maintain homeostasis (Cowieson et al., 2006). Phytase supplementation had no effect on water intake or water to feed ratio in the current trial $(P$ $>0.05$ ) (Table 2). When phytase was added to barley-based diets, Juanpere et al. (2004) noted a higher water intake in phytase-supplemented broilers when compared with the negative control group, but similar water intake compared with the positive control group. There were no differences in the water to feed ratio among chickens in the positive control, negative control or phytase treatment groups and therefore water intake rose only with an increase in feed intake and live weight (Juanpere et al., 2004). To the best of the authors' knowledge, published research about the effects of phytase on water intake in broilers is scarce, but from the results obtained in the current study and that of Juanpere et al., (2004), the conclusion can be reached that phytase supplementation does not increase water intake in broilers. Furthermore, results from 
studies on sows (Kemme et al., 1997) and horses (Van Doorn et al., 2004) indicate that phytase supplementation did not increase water intake.

No significant differences were observed for mortality among treatment groups $(P>0.05)$ (Table 2). These findings are in agreement with the results of Yan et al. (2003). In contrast, Waldroup et al. (2000) reported npP levels to have an effect on mortality. However, an increase in mortality appeared only when npP levels were lower than $2.5 \mathrm{~g} / \mathrm{kg}$. In the current study, npP levels of the diets were not available, but the lowest aP levels for a treatment diet was $1.88 \mathrm{~g} / \mathrm{kg}$. However, the decrease in aP did not significantly influence mortality percentage compared with the CON treatment group $(\mathrm{aP}=3.88 \mathrm{~g} / \mathrm{kg})$.

Bone status is important in poultry production. Phosphorus and $\mathrm{Ca}$ deficiency can increase bone breakages and defects (Brenes et al., 2003). These defects or breakages of the tibia and femur during processing result in the meat being downgraded. These fractures and deformities also influence animal welfare and subsequently affect feed intake and production (Orban et al., 1999). Reducing the $P$ and Ca levels in the diet of broilers in the NEG treatment group significantly decreased tibia breaking strength and fat-free bone ash percentage compared with broilers in CON (Table 3). Although supplementing the NEG diet with phytase increased the breaking strength and ash content of the tibia to result in values similar to broilers in the CON treatment group, the increments were not large enough to result in significant differences between the broilers in the HiPhos and NEG treatment groups. Shaw et al. (2011) reported that $1000 \mathrm{FYT} / \mathrm{kg}$ of HiPhos supplementation was able to increase tibia strength of 21-day-old broilers compared with a negative control treatment group $(\mathrm{npP}=0.22)$, although the increment was not large enough and the tibia breaking strength was still significantly less than the tibia strength of broilers receiving the positive control diet $(3.8 \mathrm{~g} / \mathrm{kg}$ of npP, $9.4 \mathrm{~g} \mathrm{Ca} / \mathrm{kg}$ ). On the other hand, Aureli et al. (2011), who supplemented diets (total $\mathrm{P}=$ $4.1 \mathrm{~g} / \mathrm{kg}, \mathrm{Ca}=6.0 \mathrm{~g} / \mathrm{kg}$ ) with $1000 \mathrm{FYT} / \mathrm{kg}$ of HiPhos, reported that the tibia breaking strength of 22-day-old broilers receiving the phytase treatment were significantly higher than the positive (total $P=5.6 \mathrm{~g} / \mathrm{kg}, \mathrm{Ca}=$ $6.0 \mathrm{~g} / \mathrm{kg}$ ) and negative (total $\mathrm{P}=4.1 \mathrm{~g} / \mathrm{kg}, \mathrm{Ca}=6.0 \mathrm{~g} / \mathrm{kg}$ ) control treatment groups. Onyango et al. (2004) speculated that different results in the literature regarding tibia breaking strength could be owing to differences in the ages of the broilers, the crosshead speed of the Instron probe, handling of the bones before testing and the site at which the shearing was done.

Carcass dressing percentage is influenced by muscle growth and visceral growth. Dressing percentage decreases when abdominal fat or visceral organ weight increases (Salma et al., 2007). No differences in dressing percentage were observed among treatments (Table 3). Similarly, Scheideler \& Ferket (2000) did not observe differences in percentage carcass yield among broilers receiving diets with different npP levels or diets supplemented with 500 FTU/kg Natuphos phytase.

It is important to look at the effect feed additives may have on portion sizes, because wholesale prices per kilogram differ among portions. This may affect profits if chickens are sold as commercial cuts. Phytase supplementation or nutrient composition (CON vs. NEG) did not affect carcass component yield $(P>0.05)$ (Table 3). These results are in agreement with Angel et al. (2006) who reported no differences in breast, wing, leg or barrel percentages when broiler diets were supplemented with $600 \mathrm{FYT} / \mathrm{kg}$ Ronozyme phytase. In the same way, Scheideler \& Ferket (2000) reported no differences in breast, wing and leg quarter weight of broilers supplemented with $500 \mathrm{FTU} / \mathrm{kg}$ of Natuphos phytase.

It is also important to consider the effects phytase might have on the appearance and physical characteristics of the meat. The colour of the meat is of critical importance, because consumers often reject products if the colour varies from the expected normal appearances (Qiao et al., 2001). Furthermore, the rate of $\mathrm{pH}$ decline and the temperature of the muscle when $\mathrm{pH}_{\mathrm{u}}$ is attained play roles in the water-holding capacity, texture and tenderness of the meat (Richardson \& Mead, 1999). Phytase supplementation had no significant effect on $\mathrm{pH}_{\mathrm{u}}$ or on the CIE $\mathrm{L}^{*}, \mathrm{a}^{*}$ or $\mathrm{b}^{*}$ colour measurements for the breast meat (Table 3). Similarly, Han et al. (2009) reported that phytase supplementation had no effect on colour or pH of broiler meat.

The surface of the small intestine contains finger-like projections, known as villi, which increase the surface area of the small intestine and therefore increase its absorptive capacity (Silverthorn, 2007). For the current study it was hypothesized that phytase supplementation will release the phytate-bound nutrients and therefore reduce the stress on the digestive tract, increase available nutrients and subsequently increase villous height and crypt depth, resulting in an increased absorption capacity. This was not the result in the current study. Treatments had no significant effect on villus height, villus area, crypt depth or villus height to crypt depth ratio in the duodenum (Table 3). Results on the effect of phytase on small intestinal histomorphology are scarce and conflicting results have been reported by authors. In the study of Smulikowska et al. (2010), shorter jejunum villus heights and deeper crypt depth were observed in chickens fed wheat, soya bean and rapeseed based diets low on $\mathrm{npP}$ compared with diets with normal P levels. Furthermore, Khodambashi-Emami et al. (2013) reported an increase in villi height and villi height to crypt depth ratio in the duodenum and jejunum, together with decreased jejunum crypt depth when maize- and 
soya bean-based diets low in aP were supplemented with phytase. However, in the studies reported by Nourmohammadi \& Afzali (2013), phytase supplementation increased crypt depth and decreased villus height to crypt depth ratio.

Table 3 Means ( \pm SE) of carcass characteristics, meat quality measurements, bone mineralization and duodenal histomorphological measurements of broilers supplemented with $1500 \mathrm{FYT} / \mathrm{kg}$ of phytase

\begin{tabular}{|c|c|c|c|c|}
\hline & \multicolumn{3}{|c|}{ Treatment } & \multirow{2}{*}{$P$-value } \\
\hline & $\operatorname{CON}^{1}$ & $\mathrm{NEG}^{2}$ & HiPhos $^{3}$ & \\
\hline \multicolumn{5}{|l|}{ Bone mineralization } \\
\hline Fat free bone ash (\%) & $52.14^{\mathrm{b}} \pm 0.75$ & $48.97^{\mathrm{a}} \pm 0.67$ & $50.51^{\mathrm{ab}} \pm 0.35$ & $<0.001$ \\
\hline Tibia strength $(\mathrm{N})$ & $241.46^{b} \pm 14.08$ & $153.06^{\mathrm{a}} \pm 6.56$ & $185.85^{\mathrm{ab}} \pm 10.74$ & 0.004 \\
\hline \multicolumn{5}{|c|}{ Carcass characteristics } \\
\hline Dressing \% & $67.41 \pm 0.60$ & $65.45 \pm 0.70$ & $67.21 \pm 0.80$ & $N S^{5}$ \\
\hline Breast \% & $33.01 \pm 0.90$ & $33.39 \pm 0.95$ & $33.60 \pm 0.85$ & NS \\
\hline Thigh \% & $26.54 \pm 0.94$ & $26.22 \pm 0.45$ & $25.35 \pm 0.49$ & NS \\
\hline Drumstick \% & $14.21 \pm 0.48$ & $14.32 \pm 0.56$ & $15.15 \pm 0.40$ & NS \\
\hline Wing \% & $13.75 \pm 0.73$ & $14.49 \pm 0.54$ & $12.87 \pm 0.49$ & NS \\
\hline \multicolumn{5}{|c|}{$\mathrm{pH}$ and colour measurements (breast muscle) ${ }^{4}$} \\
\hline $\mathrm{pH}_{\mathrm{i}}$ & $5.93 \pm 0.13$ & $6.23 \pm 0.06$ & $6.32 \pm 0.10$ & NS \\
\hline $\mathrm{pH}_{\mathrm{u}}$ & $5.70 \pm 0.09$ & $5.75 \pm 0.05$ & $5.67 \pm 0.06$ & NS \\
\hline$L^{*}$ & $55.34 \pm 1.69$ & $57.51 \pm 1.67$ & $57.91 \pm 1.33$ & NS \\
\hline$a^{*}$ & $5.12 \pm 0.58$ & $4.02 \pm 0.50$ & $4.06 \pm 0.51$ & NS \\
\hline$b^{\star}$ & $12.04 \pm 0.69$ & $11.06+0.81$ & $11.06 \pm 0.83$ & NS \\
\hline \multicolumn{5}{|c|}{ Histomorphological measurements (duodenum) } \\
\hline Villi area $\left(\mu m^{2}\right)$ & $187499 \pm 22684$ & $195408 \pm 14510$ & $232551 \pm 22675$ & NS \\
\hline Villi height $(\mu \mathrm{m})$ & $1394 \pm 115$ & $1715 \pm 105$ & $1433 \pm 93$ & NS \\
\hline Crypt depth $(\mu \mathrm{m})$ & $215 \pm 8$ & $202 \pm 12$ & $209 \pm 22$ & NS \\
\hline Villi : crypt & $6.60 \pm 0.69$ & $8.58 \pm 0.46$ & $7.09 \pm 0.59$ & NS \\
\hline
\end{tabular}

${ }^{1}$ CON: normal specification of standard feed

${ }^{2} \mathrm{NEG}$ : normal specification of standard feed the minus matrix values of 1500 FYT HiPhos

${ }^{3}$ HiPhos: NEG diet + 1500 FYT/kg of HiPhos phytase

${ }^{4} \mathrm{pHi}$ : pH at 15 minutes post mortem; $\mathrm{pHu}$ : $\mathrm{pH}$ at 24 hours post mortem; $\mathrm{L}^{*}=$ lightness; $\mathrm{a}^{\star}=$ redness; $\mathrm{b}^{\star}=$ yellowness

${ }^{5} \mathrm{NS}$ : not significant $(P>0.05)$

a,b Means within rows with different superscripts differ significantly $(P<0.05)$

\section{Conclusion}

The supplementation of broiler diets with $1500 \mathrm{FYT} / \mathrm{kg}$ of Ronozyme ${ }^{\circledR}$ HiPhos phytase enabled the authors to decrease the digestible $\mathrm{P}, \mathrm{Ca}$, crude protein and apparent metabolizable energy content of the diets by $1.7 \mathrm{~g} / \mathrm{kg}, 2.1 \mathrm{~g} / \mathrm{kg}, 2.3 \mathrm{~g} / \mathrm{kg}$ and $0.3 \mathrm{MJ} / \mathrm{kg}$, respectively, without negatively affecting bodyweight, ADG, FCR or EPEF. Phytase supplementation did not influence water intake, carcass characteristics, meat quality measurements or small intestinal histomorphology. In addition, the results of this study indicate that the increase in performance that is usually observed when broilers are supplemented with phytase is due only to the nutrient-releasing capabilities of phytase and not to improvements of the small intestinal morphology of broilers.

\section{Acknowledgements}

The authors wish to acknowledge DSM Nutritional Products, Basel, Switzerland for supplying the phytase and funding for this study. We thank the National Research Foundation (NRF) and the Protein Research Foundation (PRF), South Africa, for financial support. 


\section{Authors' contributions}

The research was conducted as part of LVE's MSc thesis in Animal Science. EP, and LCH supervised the study. All authors commented on early and final versions of the manuscript.

\section{Conflict of Interest}

The authors declare that they have no conflicts of interest with regard to this work.

\section{References}

Angel, R., Saylor, W., Mitchell, A., Powers, W. \& Applegate, T., 2006. Effect of dietary phosphorus, phytase, and 25-hydroxycholecalciferol on broiler chicken bone mineralization, litter phosphorus, and processing yields. Poult. Sci. 85, 1200-1211.

Aureli, R., Faruk, M.U., Cechova, I., Pedersen, P., Elvig-Joergensen, S., Fru, F. \& Broz, J., 2011. The efficacy of a novel microbial 6-phytase expressed in aspergillus oryzae on the performance and phosphorus utilization in broiler chickens. Int. J. Poult. Sci. 10, 160-168.

Bikker, P., Karabinas, V., Verstegen, M.W.A. \& Campbell, R., 1995. Protein and lipid accretion in body components of growing gilts $(20-45 \mathrm{~kg})$ as affected by energy intake. J. Anim. Sci. 73, 2355-2363

Brenes, A., Viveros, A., Arija, I., Centeno, C., Pizarro, M. \& Bravo, C., 2003. The effect of citric acid and microbial phytase on mineral utilization in broiler chicks. Anim. Feed Sci. Technol. 110, 201-219.

Cheryan, M. \& Rackis, J.J., 1980. Phytic acid interactions in food systems. Crit. Rev. Food Sci. 13, 297-335.

Cowieson, A., Acamovic, T. \& Bedford, M., 2004. The effects of phytase and phytic acid on the loss of endogenous amino acids and minerals from broiler chickens. Br. Poult. Sci. 45, 101-108.

Cowieson, A., Acamovic, T. \& Bedford, M., 2006. Supplementation of corn-soy-based diets with an eschericia coliderived phytase: Effects on broiler chick performance and the digestibility of amino acids and metabolizability of minerals and energy. Poult. Sci. 85, 1389-1397.

Davies, N. \& Olpin, S., 1979. Studies on the phytate: Zinc molar contents in diets as a determinant of Zn availability to young rats. Br. J. Nutr. 41, 591-603.

Deshpande, S. \& Damodaran, S., 1989. Effect of phytate on solubility, activity and conformation of trypsin and chymotrypsin. J. Food Sci. 54, 695-699.

Driver, J.P., Pesti, G., Bakalli, R. \& Edwards, H., 2005. Effects of calcium and nonphytate phosphorus concentrations on phytase efficacy in broiler chicks. Poult. Sci. 84, 1406-1417.

Fleming, R., McCormack, H., McTeir, L. \& Whitehead, C., 1998. Medullary bone and humeral breaking strength in laying hens. Res. Vet. Sci. 64, 63-67.

Han, J., Yang, X., Zhang, L., Li, W., Zhang, T., Zhang, Z. \& Yao, J., 2009. Effects of 1a-hydroxycholecalciferol and phytase on growth performance, tibia parameter and meat quality of 1-to 21-d-old broilers. Asian-Australas. J. Anim. Sci. 22, 857-864.

Hídvégi, M. \& Lásztity, R., 2002. Phytic acid content of cereals and legumes and interaction with proteins. Periodica Polytechnica Ser. Chem. Eng. 46, 59-64.

Hurwitz, S. \& Bar, A., 1971. Calcium and phosphorus interrelationships in the intestine of the fowl. J. Nutr. 101, 677-686.

Juanpere, J., Pérez-Vendrell, A. \& Brufau, J., 2004. Effect of microbial phytase on broilers fed barley-based diets in the presence or not of endogenous phytase. Anim. Feed Sci. Technol. 115, 265-279.

Kemme, P., Radcliffe, J., Jongbloed, A. \& Mroz, Z., 1997. The effects of sow parity on digestibility of proximate components and minerals during lactation as influenced by diet and microbial phytase supplementation. J. Anim. Sci. 75, 2147-2153.

Khodambashi-Emami, N., Zafari Naeini, S. \& Ruiz-Feria, C., 2013. Growth performance, digestibility, immune response and intestinal morphology of male broilers fed phosphorus deficient diets supplemented with microbial phytase and organic acids. Livest. Sci. 157, 506-513.

Kies, A.K., Gerrits, W.J., Schrama, J.W., Heetkamp, M.J., Van der Linden, K.L., Zandstra, T. \& Verstegen, M.W., 2005. Mineral absorption and excretion as affected by microbial phytase, and their effect on energy metabolism in young piglets. J. Nutr. 135, 1131-1138.

Lonnerdal, B., Sandberg, A.S., Sandstrom, B. \& Kunz, C., 1989. Inhibitory effects of phytic acid and other inositol phosphates on zinc and calcium absorption in suckling rats. J. Nutr. 119, 211-214.

Maenz, D., 2001. Enzymatic characteristics of phytases as they relate to their use in animal feeds. In: Enzymes in Farm Animal Nutrition. Edited by M. Bedford \& G. Partridge. CABI, Wallingford, Oxfordshire, UK. pp. 61-84.

McDonald, P., Edwards, R.A., Greenhalgh, J.F.D. \& Morgan, C.A., (eds.) 2002. Animal Nutrition. 6th edition. Prentice Hall, Pearson Education. Eddinburgh Gate, Harlow, Essex. pp. 118-121.

Nollet, L.M.L., Boylston, T., Cheng, F. \& Coggins, P.C., 2007. Handbook of Meat, Poultry and Seafood Quality. 1st edition. Blackwell, Ames, lowa. pp. 461-462.

Nourmohammadi, R. \& Afzali, N., 2013. Effect of citric acid and microbial phytase on small intestinal morphology in broiler chicken. Ital. J. Anim. Sci. 12, 44-47.

Onyango, E., Bedford, M. \& Adeola, O., 2004. The yeast production system in which escherichia coli phytase is expressed may affect growth performance, bone ash, and nutrient use in broiler chicks. Poult. Sci. 83, 421-427.

Orban, J., Adeola, O. \& Stroshine, R., 1999. Microbial phytase in finisher diets of white pekin ducks: Effects on growth performance, plasma phosphorus concentration, and leg bone characteristics. Poult. Sci. 78, 366-377.

Pond, W.G., Church, D.C., Pond, K.R. \& Schoknecht. P.A., 2005. Basic Animal Nutrition and Feeding. Wiley, Hoboken, $\mathrm{NJ}$, USA. 
Presnell, J.K. \& Schreibman, M.P., 1997. Humason's Animal Tissue Techniques. 5th edition. Johns Hopkins University Press, Baltimore.

Qiao, M., Fletcher, D., Smith, D. \& Northcutt, J., 2001. The effect of broiler breast meat color on pH, moisture, waterholding capacity, and emulsification capacity. Poult. Sci. 80, 676-680.

Rama Rao, S. \& Reddy, V.R., 2001. Utilisation of different phosphorus sources in relation to their fluorine content for broilers and layers. Br. Poult. Sci. 42, 376-383.

Rama Rao, S., Raju, M., Reddy, M. \& Pavani, P., 2006. Interaction between dietary calcium and non-phytate phosphorus levels on growth, bone mineralization and mineral excretion in commercial broilers. Anim. Feed Sci. Technol. 131, 135-150.

Ravindran, V., Ravindran, G. \& Sivalogan, S., 1994. Total and phytate phosphorus contents of various foods and feedstuffs of plant origin. Food Chem. 50, 133-136.

Richardson, R.I. \& Mead, G.C., 1999. Poultry Meat Science. 25th ed. CABI. Wallingford, Oxford. pp.104.

Salma, U., Miah, A., Maki, T., Nishimura, M. \& Tsujii, H., 2007. Effect of dietary rhodobacter capsulatus on cholesterol concentration and fatty acid composition in broiler meat. Poult. Sci. 86, 1920-1926.

SAS, 2009. Version 9.3. SAS Institute Inc., Cary, North Carolina, USA.

Scheideler, S. \& Ferket, P., 2000. Phytase in broiler rations -effects on carcass yields and incidence of tribal dyschondroplasia. J. Appl. Poult. Res. 9, 468-475.

Selle, P.H., Ravindran, V., Pittolo, P. \& Bryden, W., 1999. An evaluation of microbial phytase in sorghum-based broiler diets. Proc. Aust. Poult. Sci. Symp. 11, 97-100.

Selle, P.H. \& Ravindran, V., 2007. Microbial phytase in poultry nutrition. Anim. Feed Sci. Technol. 135, 1-41.

Selle, P.H., Cowieson, A.J. \& Ravindran, V., 2009. Consequences of calcium interactions with phytate and phytase for poultry and pigs. Livest. Sci. 124, 126-141.

Shaw, A., Blake, J. \& Gordon, R., 2010. Evaluation of commercial phytase enzymes on performance and tibia-breaking strength of male broiler chicks. J. Appl. Poultry Res. 19, 415-421.

Shaw, A., Hess, J., Blake, J. \& Ward, N., 2011. Assessment of an experimental phytase enzyme product on live performance, bone mineralization, and phosphorus excretion in broiler chickens. J. Appl. Poult. Res. 20, 561-566.

Silverthorn, D.U., 2007. The digestive system In: Human Physiology: An Integrated Approach. 4th edition. Pearson/Benjamin Cummings, San Francisco. pp. 676-714.

Singh, M. \& Krikorian, A., 1982. Inhibition of trypsin activity in vitro by phytate. J. Agric. Food Chem. 30, 799-800.

Smulikowska, S., Czerwiński, J. \& Mieczkowska, A., 2010. Effect of an organic acid blend and phytase added to a rapeseed cake-containing diet on performance, intestinal morphology, caecal microflora activity and thyroid status of broiler chickens. J. Anim. Physiol. Anim. Nutr. 94, 15-23.

Suttle, N.F., 2010. Mineral Nutrition of Livestock. 4th edition. CABI, Wallingford, Oxfordshire, UK. pp. 122-156.

Van Doorn, D., Everts, H., Wouterse, H. \& Beynen, A., 2004. The apparent digestibility of phytate phosphorus and the influence of supplemental phytase in horses. J. Anim. Sci. 82, 1756-1763.

Viveros, A., Brenes, A., Arija, I. \& Centeno, C., 2002. Effects of microbial phytase supplementation on mineral utilization and serum enzyme activities in broiler chicks fed different levels of phosphorus. Poult. Sci. 81, 1172-1183.

Waldroup, P., Kersey, J., Saleh, E., Fritts, C., Yan, F., Stilborn, H., Crum, R. \& Raboy, V., 2000. Nonphytate phosphorus requirement and phosphorus excretion of broiler chicks fed diets composed of normal or high available phosphate corn with and without microbial phytase. Poult. Sci. 79, 1451-1459.

Warriss, P.D., 2000. Meat science: An introductory text. CABI. Wallingford, Oxfordshire, UK.

Wu, G., Liu, Z., Bryant, M. \& Roland, D., 2006. Comparison of natuphos and phyzyme as phytase sources for commercial layers fed corn-soy diet. Poult. Sci. 85, 64-69.

Yan, F., Fritts, C. \& Waldroup, P., 2003. Evaluation of modified dietary phosphorus levels with and without phytase supplementation on live performance and fecal phosphorus levels in broiler diets. 1. Full-term feeding recommendations. J. Appl. Poult. Res. 12, 174-182.

Yoon, J.H., Thompson, L.U. \& Jenkins, D., 1983. The effect of phytic acid on in vitro rate of starch digestibility and blood glucose response. Am. J. Clin. Nutr. 38, 835-842.

Youssef, I.M., Beineke, A., Rohn, K. \& Kamphues, J., 2011. Effects of high dietary levels of soybean meal and its constituents (potassium, oligosaccharides) on foot pad dermatitis in growing turkeys housed on dry and wet litter. Arch. Anim. Nutr. 65, 148-162.

Zhang, B. \& Coon, C.N., 1997. The relationship of various tibia bone measurements in hens. Poult. Sci. 76, 1698-1701. 